\title{
E-LEARNING ON BIOLOGY BY EYES OF PUPILS FROM PRIMARY SCHOOL
}

\section{Jana FANČOVIČOVÁ}

\begin{abstract}
The report deals with the attitudes of pupils from primary schools towards e-learning in biology. We compared traditional education with education by means of informationcommunication technologies. We found out that they liked web-based education but they do not like to use this method every day. They would like to use ICT as a tool.
\end{abstract}

Key words: attitudes, web-site, ICT, pupil.

\section{HODNOTENIE ELEKTRONICKÉHO VZDELÁVANIA V BIOLÓGII ŽIAKMI ZÁKLADNEJ ŠKOLY}

Resumé: Príspevok sa zaoberá postojmi a názormi žiakov základných škôl na elektronickú formu vzdelávania na hodinách biológie. Experimentálne sme overovali tradičné prijímanie poznatkov s prijímaním poznatkov prostredníctvom informačno - komunikačných technológií. Z názorov žiakov sme zistili, že sa im vyučovanie prostredníctvom web - stránky páčilo, ale nechceli by sa takto učit' každú vyučovaciu hodinu. IKT by chceli využivat' ako doplnok vyučovania, nie ako jedinú vyučovaciu metódu.

Kl'účové slová: postoje, web-stránka, IKT, žiak.

Úvod

Postoje predstavujú skúsenost'ou získanú tendenciu k určitej myšlienkovej, emocionálnej odozve na jav, deje a problémy. Sú základom pre hodnotiace stanovisko a prezentujú orientáciu človeka a jeho vzt'ah k objektom súvisiacim s jeho činnost'ou alebo životným pôsobením (Kollárik, 1993). Podl'a Duriča (1997) ide o hodnotiaci vzt’ah, kde výraznú úlohu zohrávajú city. Môže sa vzt'ahovat' na ktorúkol'vek osobu, udalost', vec alebo jav. Postoj voči niečomu vyjadruje hodnotenie objektu subjektom, ktoré sa pohybuje v kontinuu, ktorého krajné póly tvoria úplne pozitívny a úplne negatívny vzt'ah. Každý jedinec má svoj vlastný systém postojov, a teda jeho jednotlivé postoje sú určitým spôsobom usporiadané a sú medzi nimi určité väzby (Nakonečný,1997).

Postoje žiakov k počítačovým cvičeniam na základe výskumu Ogilvia (1999) boli vysoko pozitívne. Väčšina študentov ohodnotila tento spôsob skúšania ako užitočný, menej časovo náročný a viac informatívny ako písanie na papier. Tieto názory odrážajú možnost' postupovat' vlastným tempom a mnohí uviedli, že sa zlepšila ich počítačová gramotnost'. Viac ako polovica respondentov výskumu Kubiatka (2006) tvrdilo, že IKT pozitívne vplývajú na zvyšovanie záujmu o tento učebný predmet, do priameho súvisu dávali moderné technológie s pozornost'ou, ktorú venovali biológii. IKT považovali za motivačný prostriedok vo vyučovaní.

V štúdii Kreiselovej (2003) žiaci vysoko hodnotili možnost' animácie, vizuálnu stránku (Paris, 2004) a dizajn programu. Učitelia oceňovali l'ahkost' používania počítača, možnost' redukcie času na prípravu a fakt, že nemuseli disponovat' hlbokými vedomost'ami o výžive. Žiaci radi včleňovali texty, animácie, zvuky, obrázky do projektov a kooperatívne vyučovanie vnímali ako možnost', ktorá zvyšuje počítačové zručnosti a vedomosti (84\% zúčastnených žiakov), pozornost' a záujem o počítače ( $77 \%$ žiakov), motivácia $(90 \%)$ a vzt'ahy medzi spolužiakmi (Yang, 2005).

Postoje učitel'ov k virtuálnej realite boli tiež vysoko pozitívne štúdii Mikropoulusa et al. (2003). Vyjadrili sa, že virtuálne prostredie vo vyučovaní biológie je silným vzdelávacím prostriedkom, ktorý umožňuje žiakom byt' aktívnym a tvorivým. Študenti zapojení do výskumu Shima et al. (2003) mali pozitívny postoj $\mathrm{k}$ používaniu simulácií založených na virtuálnej realite. Omnoho viac sa zaujímali o tento typ technológií ako o iné multimediálne programy a uvádzali, že je vel'mi nápomocný a jednoduchý pri vyučovaní biológie. Boli presvedčení o jeho efektívnosti a používaním 
virtuálnej reality našli motiváciu učit' sa biológiu, pocítili realitu a l'ahšie pochopili biologické pojmy. Tento typ programu by chceli používat' aj v budúcnosti, pretože mohli objavovat' a manipulovat's objektmi.

Barrett a Lally (1999) skúmali využitie počítačom sprostredkovanej komunikácie. Sledovali, ako bola on-line diskusia využitá na vzdelávanie a skúmali socio-emotívne správanie $\mathrm{v}$ skupine medzi ženami a mužmi. Zistili, že pohlavie zohráva zvláštnu úlohu $\mathrm{v}$ takomto spôsobe vzdelávania. Muži poslali v priemere viac správ ako ženy, písali správy, ktoré boli dvakrát dlhšie boli spoločenskoemotívnejšie ako tie čo odoslali ženy. Ženy zase písali interaktívnejšie odkazy ako muži. Avšak čo sa týka kognitívneho a metakognitívneho obsahu, bol podobný, ale ich sociálne a konverzačné správanie bolo signifikantne rozdielne.

\section{Metodika}

Ciel'om výskumu bolo zistit' postoje a názory žiakov k elektronickej forme vzdelávania na hodinách prírodopisu. Experimentálne sme overovali tradičné prijímanie poznatkov s prijímaním poznatkov multimediálnymi informačnými technológiami.

Výskum bol realizovaný na troch základných školách v Trnave a v Trakoviciach. Výskum trval 2 týždne (4 vyučovacie hodiny prírodopisu $\mathrm{v}$ siedmom ročníku) a zúčastnilo sa ho 138 žiakov vo veku 13 rokov, 58 žiakov v experimentálnej skupine a 80 žiakov $\mathrm{v}$ kontrolnej. Priemerný počet žiakov v triede bol 23, pričom pri každom počítači sedel jeden alebo dvaja žiaci. Vytvorili sme webovú stránku zameranú na výživu a zdravé stravovanie. Stránka bola nástrojom vzdelávania o výžive a bola určená pre žiakov siedmeho ročníka základných škôl. V kontrolných skupinách sa vyučovalo tradičným spôsobom, využívali učebnice a iné materiály okrem počítačov a experimentálne skupiny používali počítače a teda pripravenú webovú stránku zameranú na výživu.

$\mathrm{Na}$ vyhodnotenie použitel'nosti, obsahu a dizajnu web - stránky učitelia a žiaci experimentálnej skupiny dostali hodnotiaci postojový dotazník po intervencii. Postoje žiakov k IKT sme zist'ovali u všetkých respondentov $\mathrm{v}$ kontrolnej aj experimentálnej skupine pred realizáciou výskumu. Kvalitatívne informácie boli získané v skupinovej diskusii s učitel’mi a žiakmi a tiež pozorovaním hodín.

\section{Výsledky \\ Hodnotenie elektronickej výučby žiakmi}

Reliabilita dotazníka na hodnotenie web stránky bola dostatočne vysoká (Cronbachovo $\alpha=0,793$ ). Celkové hodnotenie elektronickej výučby bolo vysoko pozitívne. Z grafu 1 vyplýva, že väčšina respondentov hodnotila výučbu pozitívne (skóre 4 a 5), menej ako polovica neutrálne (skóre 3) a iba mizivé percento žiakov negatívne.

Ako vyplýva $z$ grafu 2 priemerné skóre hodnotenia tohto typu výučby bolo $3,5 \mathrm{z}$ čoho vyplýva, že žiakom sa výučba pomocou počítača skôr páčila. Porovnaním priemerného skóre chlapcov a dievčat experimentálnej skupiny sme nezistili žiaden rozdiel $(\mathrm{t}=-0,789$, $\mathrm{df}=52, \mathrm{P}=0,433)$, čiže chlapci aj dievčatá hodnotili elektronickú výučbu podobne.

Medzi skóre $\mathrm{z}$ hodnotiaceho testu a postojmi k PC nebola po kontrolovaní pohlavných rozdielov žiadna korelácia (Partial $\mathrm{r}=0,187$, $\mathrm{P}=0,18)$. Vyplýva $\mathrm{z}$ toho, že intervencia nebola účinnejšia iba $\mathrm{v}$ skupine žiakov, ktorí mohli mat' pozitívnejšie postoje k IKT.

Deskriptívna analýza výsledkov je uvedená v grafe 3. Z grafu vyplýva, že žiaci vysoko pozitívne hodnotili zaujímavost' hodiny prostredníctvom IKT (80 \%) (výrok 1) a zrozumitel'nost' textu (výrok 8). Chceli by častejšie využívat' PC na vyučovaní prírodopisu (výrok 26) a uvádzali, že takto získané vedomosti určite využijú aj v budúcnosti (72\%) (výrok 20). Tvrdili, že využitie IKT zvýšilo ich záujem o prírodopis a pomocou webstránky by sa chceli učit' aj doma (60 \%). Z názorov žiakov sme zistili, že sa im vyučovanie prostredníctvom webstránky páčilo, ale nechceli by sa takto učit' každú vyučovaciu hodinu. IKT by chceli využívat' ako doplnok vyučovania, nie ako jedinú vyučovaciu metódu. Ako hlavný dôvod uviedli, že učitel' im nové pojmy vysvetlí ovel'a lepšie. Za d'alšiu výhodu IKT považovali znížené nároky na písanie poznámok a možnost' individuálneho tempa. 


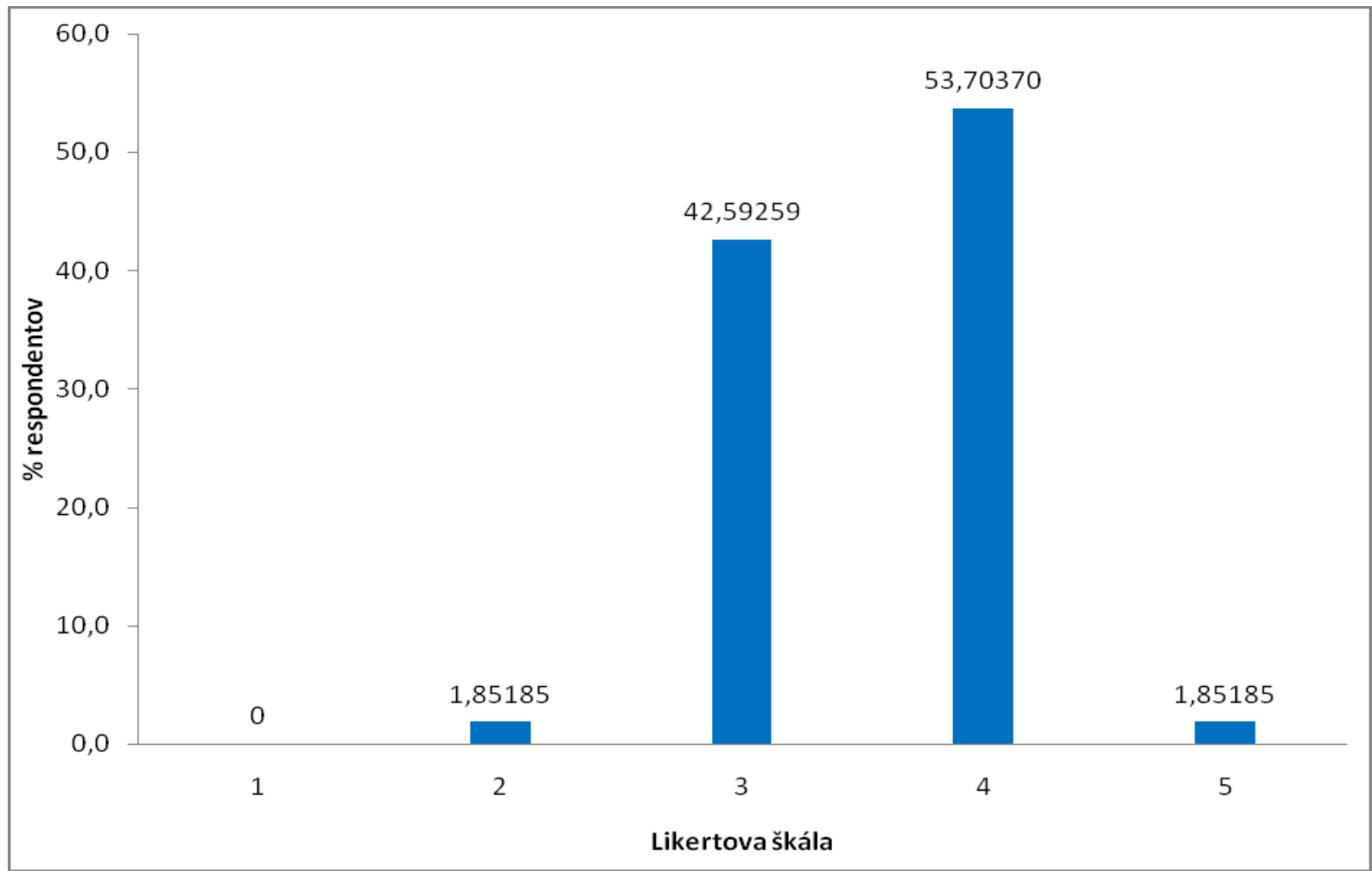

Graf 1: Distribúcia priemerného skóre hodnotenia elektronickej výučby u žiakov experimentálnej skupiny.

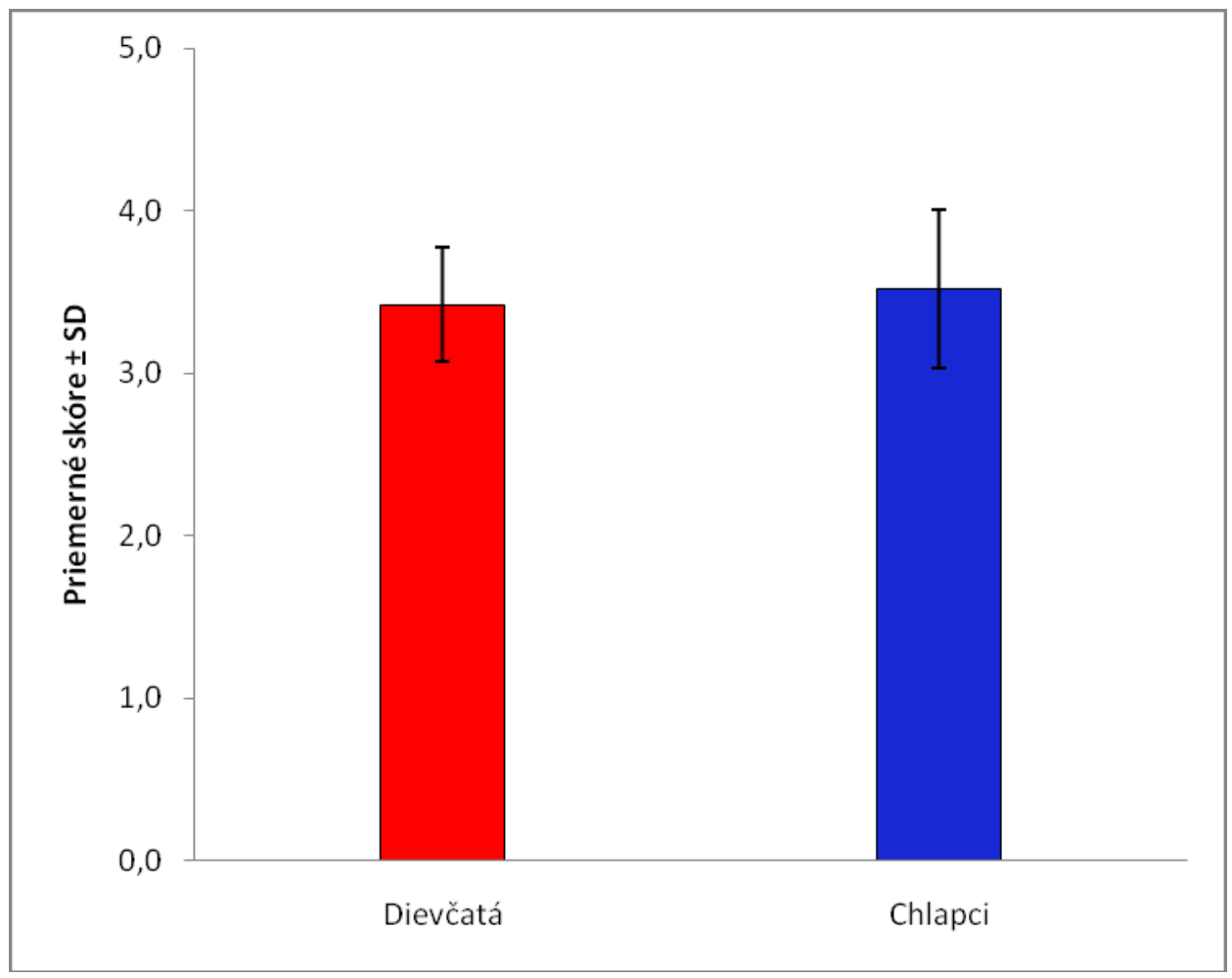

Graf 2: Hodnotenie elektronickej výučby chlapcami a dievčatami experimentálnej skupiny po ukončení intervencie. 


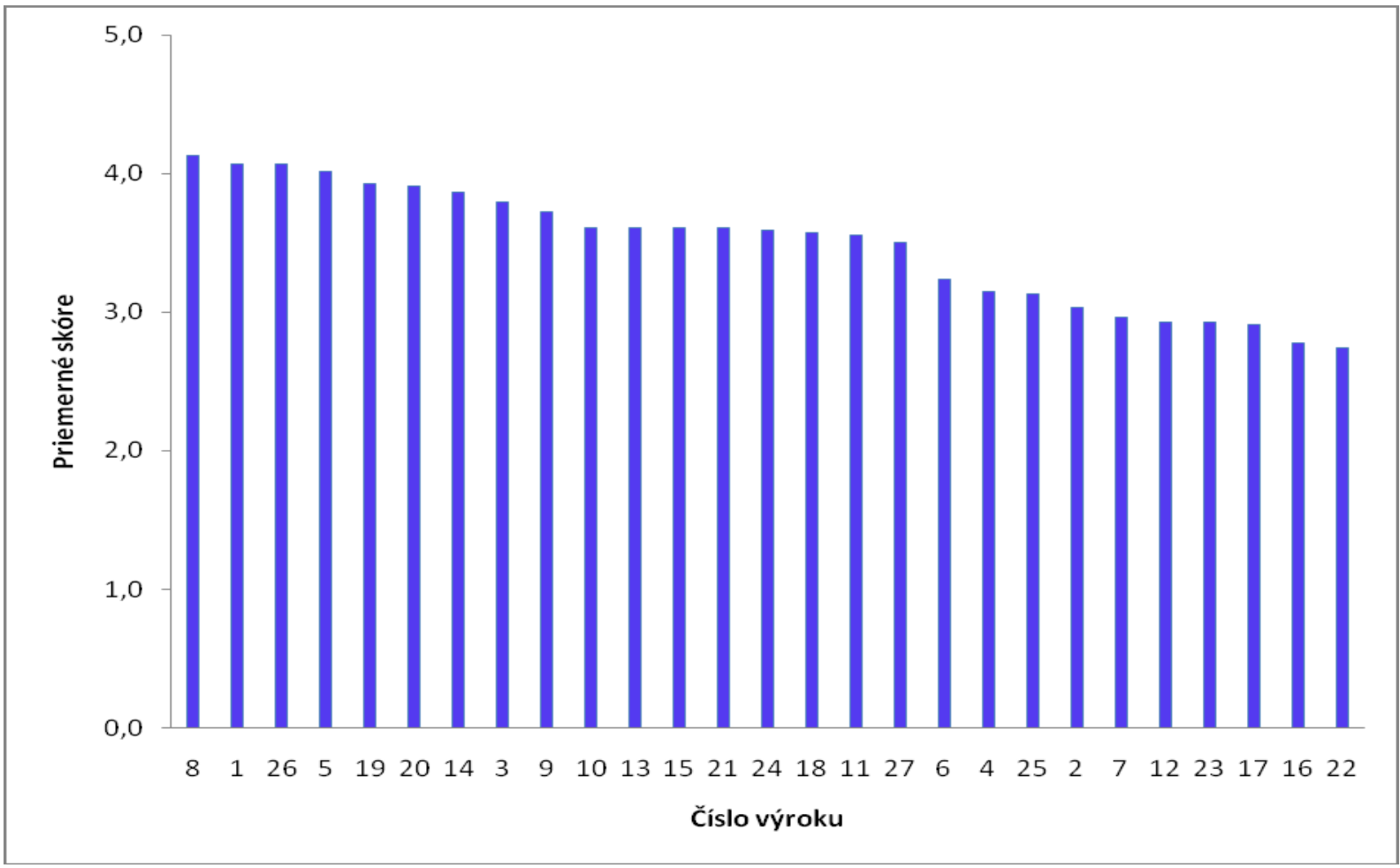

Graf 3: Deskriptívna analýza skóre výrokov zameraných na hodnotenie elektronickej výučby v experimentálnej skupine. Výroky sú zoradené podl'a priemerného skóre.

Po rozdelení dimenzií na kognitívnu, afektívnu a konatívnu stránku sme znova nezistili žiadne rozdiely medzi chlapcami a dievčatami (ANOVA, afektívna dimenzia: $\mathrm{F} 1,54=0,58, \mathrm{P}=0,45$, kognitívna dimenzia: $\mathrm{F} 1,54=0,22, \mathrm{P}=0,64$, konatívna dimenzia: $\mathrm{F} 1,54=0,16, \mathrm{P}=0,69)$.
V distribúcii celkového priemerného skóre za každú z týchto troch dimenzií neboli výrazné rozdiely. Vo všetkých prípadoch boli negatívne postoje iba výnimočné (vyslovene negatívne neboli vôbec) a vo väčšine prípadov boli pozitívne (skóre 4,0) (graf 4).

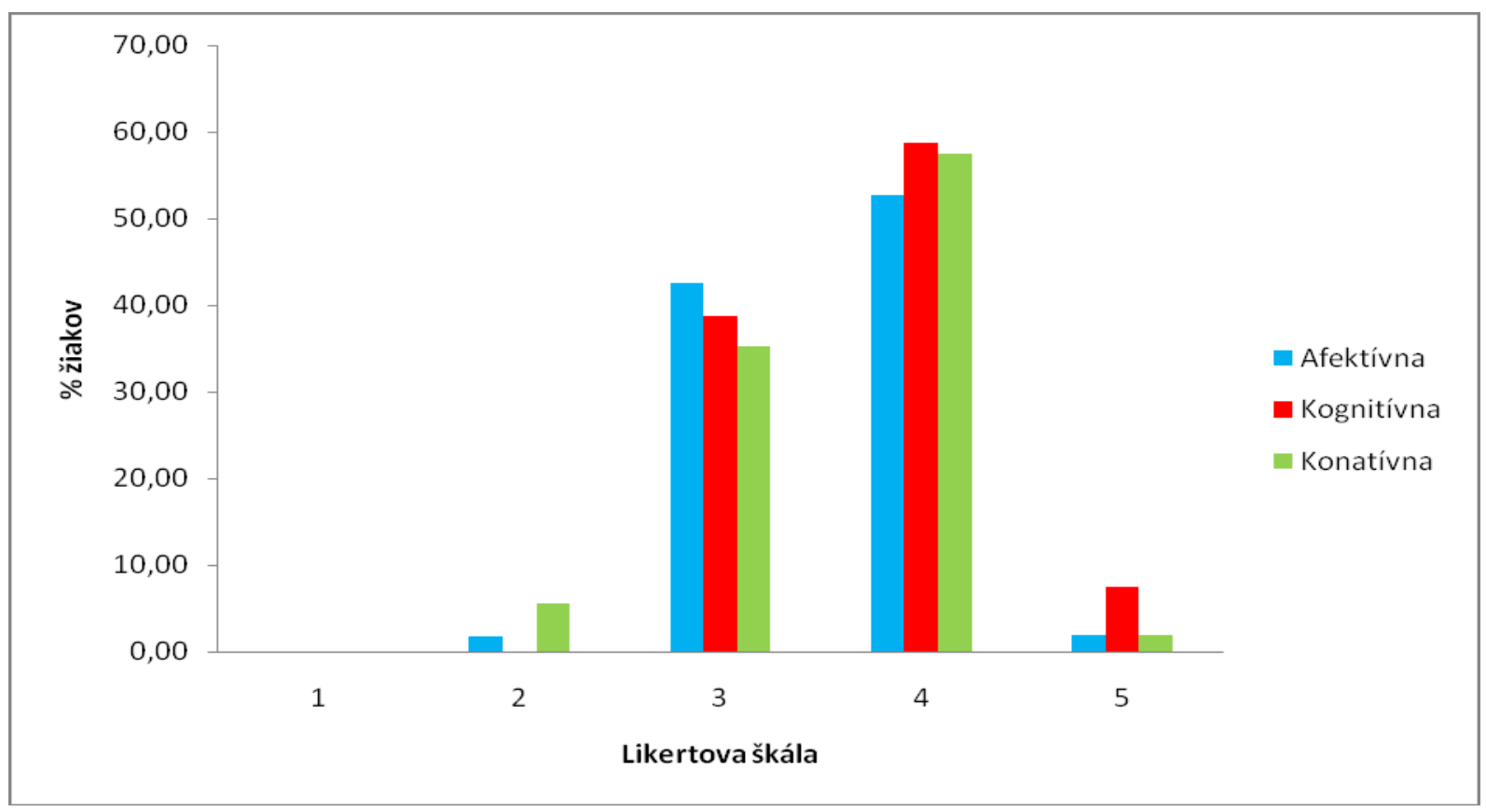

Graf 4: Distribúcia priemerného skóre troch dimenzii postojov. 


\section{Záver a diskusia}

Čo sa týka postojov $\mathrm{k}$ IKT, tie sa v našom výskume po intervencii nezmenili na rozdiel od výskumu Gardavskej et al. (2004), v ktorom u mužov pôvodne vysoký záujem mierne poklesol a u žien došlo k výraznejšiemu zvýšeniu pôvodne nižšieho záujmu o IKT.

V štúdii Paris (2004) študenti prejavili záujem o vzdelávanie prostredníctvom web stránky. Preferovali tento spôsob vzdelávania a ako dôvody uvádzali: grafika, l’ahká dostupnost' informácií, animácie a $76 \%$ študentov verilo, že toto vzdelávanie nahradí tradičné vyučovanie. V našom výskume sa študenti rovnako pozitívne prikláňali ku grafickej podobe web - stránky, ale v nahradení učitel'a boli konzervatívnejší a záujem o prítomnost' učitel'a prejavovali vo vyššej miere. Z názorov žiakov sme zistili, že sa im vyučovanie prostredníctvom web - stránky páčilo, ale nechceli by sa takto učit' každú vyučovaciu hodinu. IKT by chceli využívat' ako doplnok vyučovania, nie ako jedinú vyučovaciu metódu. Ako hlavný dôvod uviedli, že učitel' im nové pojmy vysvetlí ovel’a lepšie. Výskum Čipkovej et al.(2006) taktiež potvrdil, že študenti síce považovali videokonferencie za zaujímavé, no aj napriek tomu nemôžu podl'a nich plnohodnotne nahradit' ich priamu účast' na získavaní poznatkov. Spicer a Statford (2001) dospeli k podobným záverom pri porovnávaní vplyvu reálnej a virtuálne riadenej terénnej exkurzie.

Vo výskume Ng-Gunstone (2002) študenti uviedli, že web - stránky mali omnoho pozitívnejší vplyv na vzdelávanie vrátane motivácie pre samostatné vzdelávanie. Napriek tomu, že mnohé stránky obsahovali informácie, ktoré boli náročné na pochopenie, žiaci boli spokojní s týmto spôsobom vzdelávania. Tento výskum sa $\mathrm{v}$ mnohých dimenziách do značnej miery podobá nášmu výskumu. Žiaci v našom experimente vysoko pozitívne hodnotili zaujímavost' hodiny prostredníctvom IKT (80 $\%$ a zrozumitel'nost' textu.

\section{Literatúra}

(1) BARRET, E., LALLY, V.: Gender differences in an on-line learning environment.
Journal of Computer Assisted Learning, 1999, vol. 15 , s. $48-60$.

(2) ĎURIČ, L., BRATCKÁ, L. a kol.: Pedagogická psychológia. Bratislava, SPN 1997. ISBN 80-08-02498-4

(3) KOLLÁRIK, T.: Sociálna psychológia. SPN Bratislava. 1993.

(4) KREISEL, K.: Evaluation of a computerbased nutrition education tool. Public Health Nutrition, 2003, vol. 7, no. 2, s. 271 - 277.

(5) KUBIATKO. M.: Záujem študentov o biológiu s použitím informačných a komunikačných technológií. E - Pedagogium, 2006, vol. 6, no. 4. s. $49-59$, ISSN 1213 7758 .

(7) MIKROPOULUS, T. A., KATSIKIS, A., NIKOLOU, E., TSAKALIS, P.: Virtual environment in biology teaching. Journal of Biological Education, 2003, 37, č.4, str.176181.

(8) NAKONEČNÝ, M.: Encyklopedie obecné psychologie. Academia Praha 1997. ISBN 80200-0625-7

(9) OGILVIE, R.W., TRUSK, T.C., BLUE, A.V.: Students'attitudes towards computer testing in a basic science course. Medical education, 1999, vol. 33, s. 828 - 831.

(10) PARIS, P.G.: E-Learning: A study on Secondary Students' Attitudes towards Online Web Assisted Learning. International Education Journal, 2004, vol. 5, s. 98 - 112.

(11) SHIM, K.Ch., PARK, J.S., KIM, H.S., KIM, J.H., PARK, J.Ch., RYN, H.: Application of virtual reality technology in biology education. Journal of Biological Education, 2003, vol. 37, no. 2, s. $71-74$.

(12) YANG S.Ch., LIU S.F.: The study of interactions and attitudes of third-grade students' learning information technology via a cooperative approach. Computers in Human Behavior, 2005, vol. 21, s. $45-72$.

\section{PaedDr. Jana Fančovičová \\ Katedra biológie \\ Pedagogická fakulta Trnavskej univerzity, Priemyselná 4 \\ 91843 Trnava \\ E-mail: jfanka@pobox.sk}

